\title{
Recent Unrest in the RMG Sector of Bangladesh: Is this an Outcome of Poor Labour Practices?
}

\author{
Chowdhury Golam Hossan (Corresponding author)
}

Assistant Professor of Management

College of Business Administrations, Abu Dhabi University

Abu Dhabi, UAE

Tel: 972-501-5710 E-mail: Chowdhury.Hossan@adu.ac.ae

Md. Atiqur Rahman Sarker (Lecturer)

Department of Business Administration, East West University

43 Mohakhali, Dhaka 1212, Bangladesh

Tel: 88-017-4427-0243 E-mail: mars@ewubd.edu

Rumana Afroze (Lecturer)

Department of Business Administration, East West University

43 Mohakhali, Dhaka 1212, Bangladesh

Tel: 880-181-888-3767Ｅ-mail: rua@ewubd.edu

Received: July 2, 2011

Accepted: September 13, $2011 \quad$ Published: February 1, 2012

doi:10.5539/ijbm.v7n3p206

URL: http://dx.doi.org/10.5539/ijbm.v7n3p206

\begin{abstract}
The RMG sector of Bangladesh has experienced disputes and violent protest by the workers in recent times. This study explores the reasons for recent unrest in the garment sector. Since managers are mainly responsible for applying human resource practices, this paper has given particular attention to their views on recent attitude changes of workers. Results show that mutual understanding among workers and managers is absent in the RMG sector. This study also states that high-work load, poor behaviour of line managers, low skills and low wage rates are the notable reasons for high job turnover and social unrest. Poor relationship between workers and supervisors is the main source of conflict. This study finds that there is growing demand for work life balance among the workers of RMG sector.
\end{abstract}

Keywords: Bangladesh, Readymade garment sector, Labour management, Labour dispute, HRM

\section{Introduction}

In the age of knowledge economy and changing business environment, achieving competitive advantages and superior employee performance require proper Human Resource Management (HRM) (Becker \& Huselid 1998; \& Guest, 2007; \& Wright et al. 2003). Careful attention to the HR practices is a prerequisite to have motivated and committed employees (Becker \& Huselid 1998; \& Guest, 2007). Although large number of studies on organisational performance and employee attitudes in developed countries, very few studies can be found in the context of developing countries such as Bangladesh (Mahmood 2004). There is a rapid growth of industrialisation in Bangladesh. Most of the manufacturing companies in Bangladesh are labour-intensive, particularly the ready-made garment (RMG) industry (Huda et al. 2007). Therefore, the practice of HRM is mostly required in labour intensive industry like RMG. Moreover, there is a growing concern of labour rights among the garment workers of Bangladesh (Ahmed 2001). As a result, workers in RMG sector of Bangladesh are involving in disputes and getting involved in violent protest (Uddin and Jahed 2007). Consequently, it creates disruption in production process as workers often strike to protest against management (Huda et al. 2007). This study explores the current labour practices and its associated relationship with recent unrest in the garment sector 
of Bangladesh. Since the lower and mid-level managers are mainly deal with workers; this paper focuses on the manager's views on recent attitude changes of garment workers.

\section{RMG Sector in Bangladesh}

The ready-made Garment (RMG) sector has started its journey in the late 1970s in Bangladesh. However, Bangladesh experienced a real momentum in RMG sector between the mid-1980s and mid-1990s (Robbani 2000). The first garment factory in Bangladesh (the then East Pakistan) was established in 1960 at Dhaka (Islam 1984). Bangladesh started exporting garments in 1976. The first joint venture garment factory in Bangladesh was Desh garment in association with Daewoo, a South Korean company (Rock, 2001). Bangladesh Garment Manufacturers and Exporters Association (BGMEA) was formed in 1982 to protect the interests of the manufacturers and the exporters of RMG sector. Imposing of "Quota" restrictions on Bangladeshi products by UK, France, Canada and USA in 1985 was a critical challenge towards the growth of this sector (Uddin, 2006). Following the General Agreement on Tariff and Trade (GATT) introduction of the Multi-fibre Arrangement (MFA) allowed the use of quota restriction (Siddiqi, 2005), which facilitated the growth and expansion of garment industry. Over the years, RMG sector has experienced a remarkable export growth. RMG share is the total export increased from 12.44 percent in 1984-1985 to 60.64 percent in 1992-1993 (Siddiqi 2005). At present, RMG sector is the single largest source of earning foreign exchange in Bangladesh. Table 1 shows the trends and exports of major export products of Bangladesh

RMG sector has faced some challenges such as cleaning all internal inefficiencies, managing port effectively, building backward and forward linkages, diversifying product lines and searching for new markets due to the phasing out of MFA in 2005 (Robbani 2000). One of the weaknesses of the RMG sector in Bangladesh is its heavy dependence on imported raw materials due to inefficient backward linkage (Siddiqi 2005). The component of backward linkage includes weaving the fabric, spinning the yarn, and dyeing, printing and finishing operation (Siddiqi 2005). The development of backward linkage has been getting high priority in the post-MFA regime for achieving self-sufficiency in the area of input production for reducing cost and lead-time. Developing backward linkage refers the control over the supply of inputs of RMG industry like fabric, yarn and processing facilities (Siddiqi 2005). The ratio of gross export earnings from woven wear and knitwear has increased from 100:34 in FY1997 to 100:98 in FY2007, which ensures the structural change in export earning (Rahman, Bhattacharya, and Moazzem 2008). Interestingly, the total export of RMG sector in Bangladesh has increased after the MFA phase out, as shown in Table 2.

\section{Common Challenges in the RMG Sector}

Garment industry in Bangladesh is facing multidimensional problems such as acute power crisis followed by non tariff restriction, chronic labour unrest, lack of infrastructural facilities, inadequate supply of material and accessories, inability or lack of efforts to diversify the products and markets, irregularities relating to customs, bond, and shipping (Uddin and Jahed 2007). These major problems disrupt the production and increase the cost of production significantly. Weak and inadequate infrastructures such as poor energy supply, poor port facilities are the common challenges facing by the RMG sector in Bangladesh (Rahman and Anwar 2007). Another problem is port congestion. RMG sector often faces huge losses due to the inefficiency of Bangladesh port. To remain competitive in the world market one of the important strategies is product and market diversification (Rahman and Anwar 2007). Moreover, natural calamity often affected garment industry. For instance, due to the flood in 1998, garment order of Tk 1,000 (US\$ 15,000 million) crore could not be exported on time. More than 3 lakh workers were victim of the flood (Quddus and Rashid 1999). There are some other disadvantages that affect the competitiveness of RMG sector. Hartals (Strike due to political reason) and inadequacy of infrastructural facilities undermine Bangladesh's position in the international market (Abdullah 2005a). Furthermore, the productivity of Bangladeshi workers is one-fourth of that of Chinese. The main reason is low literacy rate. Only 25 unions are active among 200 unions registered in the garment sector. Local experts report that only 20 percent of workers receive the minimum legal wage for all hours including overtime (Clark and Kanter 2010/2011). Empirical studies have proved that any expenses for improving working condition are offset by the productivity gains in the case of RMG sector (Berik and Rodgers 2008). RMG exports are also influenced by external factors. For instance, after the terrorist attract on September 11, 2001, export to the United states declined by 2.34 percent in 2003 and 13.04 percent in the middle of 2004 (Abdin 2008).

The post-MFA trade environment has created a dual challenge to Bangladesh: firstly, Bangladesh has needed to access raw materials at a competitive price and also RMG sector is now competing with hitherto restricted countries in a quota-free environment (Bhattacharya and Rahman 2001). Handling charge for a 20-feet container in Chittagong port was \$640 compared with \$220 in Colombo and \$360 in Bangkok (World Bank 1999). 
Inefficiencies of Chittagong port are costing the economy as much as $\$ 600$ million annually (World Bank 1999). From opening of letters of credit to the clearance of goods from customs involves several complicated and time-consuming steps (World Bank 1999). The hidden costs (bribe) paid by importers per delivery ranged from Tk.4,700 to Tk.36,800 (about US\$100 to \$735) (CPD Survey 1997). These inefficiencies and corruption adversely affect competitiveness of Bangladeshi garment in the world market (Robbani 2000).

\section{Labour Practices in RMG}

Garment sector is one of the major sources of industrial employment in Bangladesh. The size of employment was about 2 million in 2007 with a 24 percent yearly growth of employment (Rahman et al 2008). Moreover, it has created employment opportunities for millions of women. RMG sector grew by satisfying its clients across the world, including the USA and Europe (Rahman and Anwar 2007). Abolition of quota system in 2005 has introduced new competition for Bangladesh from the rest of the world, especially from India and China. India and China have an added comparative advantage over Bangladesh since they have skilled labour forces, advanced technology and more importantly backward linkage support (Abdullah 2009). The key advantage of Bangladesh such as cheap labour force has been offset by other countries through superior productivity of skilled labour forces, modern infrastructure facilities and political stabilities (Abdullah 2009). Bangladesh is further challenged because most of the labours are unskilled with low productivity which results in increased per unit cost of production (Chowdhury, Ali and Rahman 2005). A study in RMG sector reported that 20 percent workers in sample enterprise are unskilled, 30 percent workers are semi-skilled, and who mainly are junior operators (Rahman, Bhattacharya and Moazzem 2008). Forty-four percent senior operators are skilled of total workers and only 5.7 percent are professional and management staff in the total workforce. The proportion of skilled workers is high in large factories (46-53\%) than small and medium factories. The proportion of unskilled workers is high in small and medium enterprises (18-26) than that of large enterprises (16-18). (Rahman, Bhattacharya and Moazzem, 2008).

However, the RMG firms in Bangladesh have been facing immense pressure from international buyers for compliance with their codes of conduct so that it needs to concentrate on improving the working environment in factories (Haider, 2007). Workers have limited choice of job environment due to high unemployment rate (Sarker 1997). Moreover, labour turnover in garment industry is very high as well (Sarker 1997). A study has found that 74 percent in knit factories, 68 percent in woven enterprises, and 81 percent in sweater factories do not provide appointment letter to the workers (Rahman, Bhattacharya and Moazzem, 2008). The wage rate in Bangladesh has increased comparing to other competing countries due to shortage of skilled labour force. It finally reduces Bangladesh's competitive advantage in terms of labour costs. The garment industry in Bangladesh is labour intensive, so potential skilled labour force is necessary (Abdullah 2005a).

The only abundant resource in the RMG sector is pool of human resource and the workers are reliable, adaptable and responsive to training (Spinagager 2001). Competitiveness in the RMG sector depends on the productivity of RMG workforce (Abdullah 2009). Work environment and job satisfaction are two primary factors that influence the productivity in the RMG sector (Abdullah 2009). RMG manufacturing companies can increase productivity by increasing job satisfaction and by improving work environment. Competitiveness in the RMG industry depends on enhancing workers productivity that also depends on improving working environment and job satisfaction. Job satisfaction increases the employee morale through giving worker's psychological comfort and incentives. Working environment increases the mental motivation. The factories with lower productivity have workers with low job satisfaction and poor working condition. However, job satisfaction has more influence on the productivity of workers compared with working condition (Abdullah 2009).

\section{Recent Labour Unrest in RMG Sector: Events and the Possible Reasons}

The RMG sector has economic contribution as well as social contribution in Bangladesh. It has created employment opportunities for about five million people including young, poor and illiterate women. However, recently the RMG sector is going through severe disturbances. The clashes between garment workers and law enforcers create serious crisis in this industry (Islam and Ahmad 2010). In January 11, 2010, the garment workers created violence for getting the facilities such as lunch bills and encashment of casual leaves. Forty workers were injured, production of 30 garment factories were halted. The garment workers had created another aggression on April 28, 2010 for increasing their monthly wage rate from US\$ 25 to US\$ 70 . During that incidence, more than 22 RMG factories were affected and 30 peoples were injured (Islam and Ahmad 2010). The wage rate (0.25 US\$ hour) is the lowest in Bangladesh compare with other countries like China (0.35), Vietnam (0.40), Pakistan (0.40) and India (0.60) (Siddiqi 2005). Overtime allowance is also inadequate in the garment sector in Bangladesh (Sarker 1997). 
Another major worker disputes had taken place on May 25, 2010 for low house rent allowance. Thirty peoples were wounded, a police station was burned down and many roads were blocked for several hours. Another worker unrest took place on June 21, 2010 for implementing minimum wages of US\$ 70 a month. In that clash, two hundred peoples were injured and thirty factories were ransacked (Islam and Ahmad 2010). The garment workers had violated at Dhaka on June 30, 2010 for protecting the closure of factories, and more then 40 people were injured. The workers have been engaged in street protest, picketing, or blocked of a manager's office or a factory for expressing their dissatisfaction about their wages and other job related issues.

One of the reasons for this unrest in the garment industry is legal and institutional failures to ensure labour rights (Islam and Ahmed 2010). Most of the garment factories in Bangladesh do not follow the labour law and ILO conventions (Islam and Ahmed 2010). The Labour Act 2006 (called Labour code) clearly mentions that the wage of a worker must be paid within seven workings days [Section 123 (1)]. Majority factories do not provide appointment letters/contract letters, identity cards and employee handbooks. Health safety and security condition in this sector are also insufficient. The workers do not have a clear idea about their rights and labour laws (Islam and Ahmed 2010).

There are some important causes that reduce productivity in the garment sector. Issues like unresolved labour conflict and poor teamwork result in firm's ineffectiveness, low motivation, boredom for specialised work, rapid technological change and high cost that reduced innovation (Abdullah 2005b). The most common reasons of labour unrest in the garment sector are wage rate and unpaid wage. Some garment owners do not pay salaries and overtime allowance to the workers on time (Uddin and Jahed 2007). However, owners claim that more than 90 percent factories pay worker's wages within $1^{\text {st }}$ and $2^{\text {nd }}$ week of the month (Rahman, Bhattacharya and Moazzem 2008). Political unrest at the national level often influences violence at the RMG sector (Uddin and Jahed 2007).

Sometimes women workers work until 3 o'clock in the morning for meeting their shipment deadlines (Jamaly and Wickramnanyam 1996). In most of the factories in the RMG sector, daily working hour is 8.28 hours (excluding overtime working hours) (Rahman, Bhattacharya and Moazzem, 2008). Women generally choose to work in the RMG sector due to their poor economic condition with little or no control over their income (PaulMajumder 1998). In fact, women face discriminations at work in terms of wage differentials and gender differences. They are working in poor condition and feel insecurity. (Hossain, Jahan and Sobhan 1990).

The women workers are living under the poverty line because of their low wage. They cannot maintain their basic cost of living so that they try to increase their income by working overtime (Absar 2001). Until 2010, the minimum wage of US\$ 43 per month has not yet implemented. Still they are living below poverty line (Clark and Kanter 2010/2011).

\section{Theoretical Background}

Human resource management (HRM) deals with people working in an organisation by designing and coordinating different employee management activities (Lloyd \& Leslies 2000). HRM is the essential factor for sustainable competitive advantage and success of any organisation (Khan 2010). Schuler (1990) mentioned that the practice of HRM enables firm to achieve resource optimisation and continuous improvement in production. A firm's productivity and quality of its services largely depend on the quality of human resources practices in respective organisation (Taylor 2008).

The strategic role of HRM is well recognised and the HR practices have direct connection with employee and organisational performance (Huselid 1995). There are several reasons behind this positive relationship between HRM practices and firm's productivity. First, if the firm invests on human capital it may increase the worker's productivity (e.g. Batt 2002). Second, job enlargement and increasing autonomy of workers will decrease the amount of wastage and the inefficiency rate in production, as the firm takes the advantage of unused skills from non-managerial workers (Appelbaum et al. 2000). Here more emphasis is given into the high performance HRM practices with "good" HRM policies in order to provide job satisfaction. Third, good HRM practices increase the motivation of workers due to increased job satisfaction (Ichniowski et al. 1997). Fourth, good HRM policies reduce the rate of job turnover that consequently trim downs the cost of recruitment and selection, and increases the benefits of investments in human capital (MacDuffie 1995). Fifth, higher employee motivation will raise the tendency among the workers to do better job, and it will also increase their commitment towards the organisation (Ichniowski et al. 1997). Thus, HRM practices bring positive changes in worker's attitudes in order to increase firm's productivity.

According to Huselid (1995), compensation, promotion and performance evaluation have positive impact on overall organisational performance. In developing countries such as Bangladesh with lower per capita income, 
these three HR practices significantly drive employee's behaviour and attitudes for better performance towards organisational goals. Because financial earning and social status are perceived as major determinants of employee's performance in labour-intensive manufacturing industry (Khan 2010). Marchington and Wilkinson (2008) note that financial rewards play crucial role in attracting and retaining skilled workers. Well-paid employees give their best effort in performing their job role. Promotion and performance evaluation practices have significant positive relationship with employee performance (Guest 2007). These HR practices lead to employee commitment and higher job satisfaction which ultimately increases the firm's productivity. Resource based theory of the firm also contended that HR practices create competitive advantage through influence over employees skills and motivation (Wright et al. 2003). Different HR practices can increase the skill and knowledge of the employees. HRM practices can contribute to superior productivity by improving the quality of employees work Life (Huselid 1995).

Although good practices of HRM increase organisational performance and create a pool of committed work force, insufficient or absence of appropriate HR practices will result in job dissatisfaction, employee turnover and lower productivity (Birdi et. al. 2008; \& Huslelid 1995; \& Taylor 2008; \& Zawiah and Taha 2006). According to Marchington and Wilkinson (2008), HRM is a distinctive approach of employee management to achieve competitive advantage through job satisfaction and commitment. However, insufficient practice of HRM will reduce employee morale and motivation that creates high job turnover. If the employee turnover rate is high in an organisation, it develops negative attitudes among the existing workers and reduces employee work motivation and performance (Holtom et.al., 2005). Organisation faces the loss of job specific skill, disruption in production and higher cost of hiring and training of new workers (Hughes and Bozionelos 2007). Taylor (2008) suggests that workers with lower motivation and commitment are always looking for switching the organisation.

Job dissatisfaction by definition is the unpleasant condition and feeling of the employees that result in lower job performance to withdrawal behaviours as absenteeism or turnover (Miller and Rosse 2002). Job dissatisfaction can arise due to several factors such as inadequate pay and promotion, lack of training and development, absence of effective performance appraisal, high work load, poor relationship between employees and managers, improper working environment, hiring wrong people and lack of psychological contract (Birdi et. al. 2008; \& Marchington and Wilkinson 2008, Taylor 2008).

Due to lack of proper HR policies and procedures, labour-intensive manufacturing firms are facing shortage of workers, and high job turnover in developing countries such as Bangladesh (Mahmood 2004). Manufacturers always focus on lower cost of production with minimum wage that brings dissatisfaction among the workers. At the same time, organisation faces high job turnover, voluntary absenteeism and tentative lateness due to lower pay and benefits (Samad 2006). Besides that poorly functioning human resource department reflects the uncompetitive position of the organisation in the market place (Becker and Huselid 1998). Poor HR planning and management is one of the main reasons of labour shortage, and it indicates that human resource strategy is not aligned with organisational goals and objectives. The labour shortage disrupts business operation. It creates higher work load for existing workers and increases work stress and reduces employee motivation (Ichniowski et al. 1997).

Apart from job dissatisfaction and turnover, poor HRM practice results in many other problems in the organisation. Guest (2007) notes that insufficient HRM practices lead to conflict among the workers and affect the relationship between employers and employees. An imbalance between work and family life brings negative changes in employee attitudes and behaviour (Miller and Rosse, 2002). Work ethics also affected due to the negative attitudes of the workers where there are personality conflict and non-existent of team work (Zawiah and Taha 2006). Consequently, workers become reluctant to follow the direction of management. It is found that labour rights are also violated by improper HRM practice that encourages labour movement (Huda et al 2007).

\section{Research Methodology}

This study has conducted three Focus Group Discussions (FGDs) in a garment factory and a textile mill of Urmi group. The FGDs have taken place between March and April 2011. FGDs is a semi-structure data collection method from a selected group of people to discuss issues and concerns listed by a researcher or a facilitator (Powell and Single 1996; \& Rabiee 2004). It is a qualitative research approach to collect data from target audience. Questions are asked for the interactive group where participants feel free to talk on the issue. FGD becomes popular and important for the research in business and social science, as group discussion discovers the information that other also believe and all those data are less accessible without discussion (Henderson 2009; \& Morgan and Spanish 1984). All the data collected through FGD are based on the synergy of group interaction. 
FGD also enables researchers to gather larger amount of information in a shorter period, and the information can be used at the preliminary or exploratory stage of any study (Powell and Single 1996).

Data collected through FGDs are analysed through systematic and rigorous process where data are coded for key issues (Morgan and Spanish 1984). However, the process of data analysis begins during the data collection. According to Rabiee (2004), rich data must be generated by skillfully facilitating the discussion. In this research study, all the FGDs have been tape recorded and all the complements by the participants have been noted down. Transcripts were made following the tape and notes. Data are then sorted out and interpreted based on the context, internal consistency, frequency and extensiveness of comments. Result has been presented with reference to corresponding participants. For example, F3:8 means $8^{\text {th }}$ participant of the $3^{\text {rd }}$ FGD who is an assistant manager in Urmi group.

\section{The Case Study Organisation}

Urmi group is one of the fastest growing and rapidly diversifying group of companies in Bangladesh. It was established in 1984. It consisted of Urmi Garments Ltd., Attires Manufacturing Company Ltd. and Fakhruddin Textile Mills Ltd. The group has given more emphasis on different types of knitted fabrics and garments. Urmi Group's product lines include: T-Shirt, Polo Shirt, Tank Top, Shorts, Trousers, Fleece Jacket, Vest and Ladies Dresses. Urmi Group mainly produces Men's, Ladies', Boys', Girls' and Infant's garments. Urmi Group uses modern and updated machineries. Urmi group has 1,350 set of Machines, and their production capacity is 63,000 pcs per day. The company's products are exported to France, Sweden, USA, Germany, UK and Spain. Main buyers of Urmi Group are La Redoute, Ellos, Bryllane, LIDL, S. Oliver, The Outdoor Group, Losan, Regatta, Wal-Mart and Avenue. The production units are equipped with sophisticated equipment imported from USA, UK, China, France, Italy, Taiwan, Thailand and Japan. The Company participates in different trade fairs in home and abroad to explore new markets around the globe. The total number of employees of Urmi Group is 5000 . Among the employees, 3,650 are skilled workers and 350 are supervisory managerial staffs. The production team comprises of skilled labourers and around 70 percent of the workforces are women. In general, Urmi Group collects fabric from its sister concern Fakhruddin Textile Mills Limited (FTML). For motivating the employees, they are giving attendance bonus, efficiency bonus and best employee award at the year end. Urmi group always evaluates workers staying long period with them. They honour the workers with cash and commodity prizes for serving 5 years, 10 years, etc. They also provide compensation for 2 or 3 years of services.

Majority of workers in Urmi group are young. Twenty-five percent of workers are aged between 18 and 23 years, 45 percent are between 24 and 29 years, 20 percent are aged between 30 and 35 years and only 10 percent workers are aged above 36 . Nearly 65 percent workers are working with Urmi group for less than 3 years. 25 percent are working for four to six years and only 10 percent of the workers are working with Urmi Group for more than 7 years. Eighty-five percent of workers earn on an average below US\$ 78. Only 15 percent workers earn between US\$ 80 and US\$ 90 dollars. Male-Female ratio in Urmi Group is 40:60. Forty percent of workers have below grade five level of education, 40 percent of workers have below grade ten level of education and 13 percent of workers have passed the school final. Only 7 percent of workers have education above school final level. The list of participants in the FDGs is presented in Table 3.

\section{Results}

The following section presents the results of the FGDs with the managers of Urmi Group. Major issues highlighted during FGDs includes the roles of trade union and labour rights, conflicting relationship with first line supervisors, demand for work-life balance, self-respect and participation, job turnover and absenteeism, efficiency and productivity of workers, workers motivational issues, and key reasons for recent unrest in the RMG sector.

\subsection{Role of Trade Union and Labour Rights}

Traditionally, trade union plays critical role in ensuring workers right in a particular industry. Although garment sector in Bangladesh has a history of nearly thirty years, trade union in this sector is fairly a new phenomenon. However, participants claim that garment workers are aware of their employment rights. They often ask for legal support from labour union and agencies. Workers are more aware of their wage details, job termination benefits and the process of ensuring termination benefits through legal action. For example, workers now complain to the wages department if there is any miscalculation in overtime (F2:1). Alongside with trade union, garment workers are also supported by various NGOs such as AWAZ (the most active NGO working for RMG workers) and other legal right agencies. Manager of a human resource department reported that in many cases workers threaten for legal action to the management in different issues, termination benefits for instance (F2: 7). Workers are more aware of their job security, employment rights (F1:6 \& F2:1, F3: 8 \& 9). However, managers complain that some 
workers misuse their opportunity to get access of legal support. For example, in some cases where workers changing their jobs due to a better opportunity, they go to Awaz (legal support agency for labour right) to get their termination benefits and last salary by accusing forceful employment termination (F3:8 \& 9).

\subsection{Conflicting Relationship with First Line Supervisors}

Several participants reported that poor relationship between workers and first line supervisors (FLS) is a common source of conflict. First line supervisors are promoted from workers and they prefer workers to follow the chain of command in every type of communication (F2:7). Supervisors are often accused for failing to ensure fairness in dealing with workers in many issues such as recommending workers holiday, leave and overtime payments (F2:6 \& F2:7). First line supervisors react negatively for any direct communication between workers and administration or HR department (F2:7). On the other hand, Urmi group encourages direct communication and follows an open door management policy (F3:7). However, management always asks for details of the incident from supervisors to maintain chain of command in the case of any complain (F2:6 \& F2:7). Management prefers to resolve conflict through discussion between both parties (F1:2).

Participants believe that mutual understanding among the workers and supervisors are critical in maintaining sound working condition (F2:6). Supervisor's attention to listen workers' complains is a prerequisite for a better mutual relationship (F1:1 \& F1:3). Well-behaved supervisors are reported to be more successful in achieving higher worker productivity (F3:7).

\subsection{Demand for Work-life Balance}

Garment sector workers are becoming more conscious about work-life balance. Workers in the garment sector are reluctant to take extra work-load, avoid long shift, do not prefer to work in the week-end, and even dislike overtime in many cases (F2:6 \& F3:9). Financial benefits seem to be no longer much powerful to keep the workers for overtime. For instance, a finishing manager presented a case where a women worker regrets to work overtime after $7 \mathrm{pm}$ so that she can watch schedule TV programme (F2: 6). The garment company with less work pressure and overtime facility attracts more workers (F2:6). Participants argue that higher wages rate, increasing number of working couples and availability of micro loans are drivers for better work-life balance (F2:7; F3:5; \& F3:7). On the other hand, employers are providing free food, maternity leave, day care centre for worker's kid and so on to gain the worker's loyalty and commitment towards the organisation (F3:2). Moreover, workers do not prefer job sharing and job rotation. For example, workers dislike relocation among different floors (F2:5). They often consider their team as family, often couples/siblings are working together and like to keep self-comfort (F2:2; F2:4; F2:6; F2:7). Managers often allow change in work floor/work line when there is a lack of good relationship among the co-workers and supervisors or as a punishment for poor performance of the respective worker (F2:3).

\subsection{Need for Self-respect and Participation}

A large number of managers observed that sense of self-respect among workers in the garment sector is increasing (F1:1; F1 2; F1:3; F2:5; \& F2:6). Supervisors and managers need to show respect and positive attitudes towards the workers to have sound working environment (F2: 6). Comparatively skilled workers are more sensitive to self-respect and often decide to resign from the job if they feel lack of self respect (F1: 3 \& F1:8). Unlike the past, workers are no longer can be forced to follow the management decision. Workers feel valued when they are given chance to participate in decision making (F3: 9). Management decision is often altered based upon employee reaction, and employee suggestions (F3:7 \& 8). One of the key responsibilities of supervisors is to convince workers about the management decision (F1:3 \& F1: 8). In some extreme cases, lack of workers participation in decision making results in either threaten to resign or show reluctantness to follow that decision (F3: 8). Unfortunately, some workers consider performance feedback as against self-respect. For instance, an assistant production manager presented a case where a skilled worker has threatened to resign for providing performance feedback.

\subsection{Job Turnover and Absenteeism}

There is a strong relationship exists between the location of the factory and workers absenteeism. Workers who are living far from factory and working at night-shift are tend to be more absent at work (F3: 8). Garment industry is experiencing high labour turnover which has negative impacts on their productivity. High work-load, poor behaviour of the supervisors, lack of required skill, lower wages rate are the notable reasons for high job turnover (F1:3; F2: 4; F2:6; F2:7; F3:10). Interestingly, a worker gets around US\$ 5 to US\$ 10 increment in monthly salary if he or she changes to a new job (F2: 4, $6 \&$ 7). However, there is an adverse relationship between level of education and job turnover. Literate workers are more aware of their rights and job 
responsibilities (F2:7). Frequent job changing incurs huge opportunity cost for the workers as they lose the option of getting bonus, and other long-term benefits. Getting another job also takes time and they become temporarily unemployed. Most of the workers who switch job frequently are not often aware of their long-term employment benefits. Workers working for many years in the company leave the job by formal notice, and they usually get all the benefits. On the other hand, the frequent job leavers leave the job just after the payment of salary without prior notice and they do not care about their long-term employment benefits and even the salary after their last cut-off day. Workers also get influenced by peer group. If their friends leave the company, they also like to move out (F1:6). Another reason for high job turnover is lack of salary standard for the workers in the garment sector (F2:3).

\subsection{Efficiency and Productivity of Workers}

Participants think that both motivation and procedural punishment for the workers are needed to increase productivity and efficiency (F3:2). Presence of performance based reward and punishment systems helps to increase workers efficiency and thereby productivity. For example, participants advise that a poorly performing worker should get least priority for overtime or if anyone does any unfair means, 7 days unpaid suspension can be issued. However, participants suggest that punishment should be given by following proper procedure. Human Resource manager reported that termination with benefits is cheaper than dealing with disciplinary action (F2:7). To make workers motivated and increase productivity, they should be rewarded for their hard work and punctuality. For example, award for $100 \%$ attendance, extra payment for best performer are the catalysts for motivating workers. Work coordination is also important to increase productivity and meet specific production target (F3:9). Participants believe that sound employee behaviour and efficiency bonus help to meet the target and increase productivity (F3:8 \& F3:11). Residence facility, recreational activities at workplace, free nutritious food for physical strength and good work relation make workers more sincere (F3: 10).

\subsection{Workers Motivational Issues}

Motivating workers for higher productivity is the most critical challenge for the managers in garment sector. Traditionally, supervisors used to apply forces to the garment workers for achieving target. Supervisors are no longer allowed to apply any forces or abuse the workers (F1:4). As a result, supervisors need to motivate workers to improve their performance (F1:2). A manager reported that workers often tend to work at a lower capacity so that supervisors cannot measure their actual work capacity during the work-study period. He further added that workers hide their actual capacity to avoid extra work load or to work in a comfortable speed (F1:3). Another participant added that workers work at a lower capacity to avoid future work load (F1:5)

Financial benefits are motivating tool in the RMG sector. Performance based reward, extra payment for additional production and established long term pay plans (pensions or provident fund) for the workers help to improve performance (F1: $6 \&$ F3:1). Efficiency bonus for achieving target isgiven on group performance in the garment sector. However, workers prefer to be judged by individual performance rather than the group (F1:3 \& F1:6). A participant suggests that employees will be motivated towards high performance if front line supervisors identify high performing workers and appropriately reward them (F1:6). Failure to appropriately recognise a high performing worker results in dissatisfaction and in some cases job turnover (F2:3). Interestingly, money is not sufficient enough to motivate workers to work on the weekend or overtime in the late evening, according to some managers (F2:6). Workers do not prefer to work in a garment factory where working on the weekend or working for overtime in the late evening is too frequent. One participant reported that workers work at very high capacity if they are allowed to leave early at the completion of their current assignment (F3:4). Moreover, though workers get over time payment, extra work target decreases their performance. That means allowing workers to have more time for their personal life motivates them to work at a high performance. Good behaviour of managers, competitive employee benefit package, social events (like picnic) have positive impact on worker's commitment and performance (F3:7 \& F3:11).

\subsection{Reasons for Recent Unrest in RMG Sector}

Participants were asked to share their opinions about the causes of recent unrest in the garment sector. Most of the participants believe that influence of external factors is the major reason for current unrest in the garment sector (F1:1; F1: 3; F1:6; F3:1; F2:4). For example, some garments where payment are quite high also experience labour unrest (F1:1; F1: 3; \& F1:6). Participants reported that there are some external groups always tries to create rumour about unfair management practices so that workers become restless and create dispute against the garment management. Dispute in a garment factory also have influence on the workers of another garment factory to create further disputes (F3:1 \& F1:1). Apart from the external influences, there are antitrust relationships exists between workers and management. The workers believe that they are always exploited by the 
management. Labour unions are promoting this views(F2:4). Poor relationship among workers and the front line managers (FLMs)/supervisors are reasons of labour unrest in garment industry (F2:3). FLMs or the supervisor's poor behaviour makes the workers stubborn and reluctant to work, and it often creates disputes among the workers in garment factory (F1:1\&2). Moreover, if management does not solve worker's problem quickly, it also creates disputes (F3:7). A participant reported that strict supervisors sometimes get support from top management due to their high achievement (F2:7). Prompt and participative management approaches to complain are effective remedy to resolve worker's disputes.

\section{Discussion and Conclusion}

Ready Made Garments sector is the largest source of foreign exchange earning in Bangladesh and a large number of people is employed by this sector ( Siddiqi 2005). However, it is evident that workers are frequently creating unrest in this sector. Poor labour management such as lower wage rate (Abdullah 2005b; \& Clark and Kanter 2010/2011), late payment of wage, inadequate overtime allowance, low house rent allowance (Khan 2010), gender discrimination (Haider 2007), lack of training, inadequate promotion, high work load, absence of effective performance appraisal, poor relationship between workers and supervisors, insufficient safety and security condition, relocation among different floors, lack of self-respect, lack of workers participation in decision making, and forcing workers to achieve target in some garment factories are contributing to this unrest. Some other factors such as low literacy rate (Haider, 2007), availability of semiskilled workers, lack of awareness about labour rights and labour laws and wrong practice of various NGOs and legal agencies are also found liable for poor working condition in the RMG sector (Clark and Kanter 2010/2011). This study also reveals that adherence of workers to rumour about unfair management practices and influences of peer group are significant sources of unrest.

It has been uncovered that the overall status of HRM practices in RMG sector is moderately low (Huda et al. 2007). RMG factories in Bangladesh face high rate of temporary labour crisis, as turnover and absenteeism rate are very high. This study also states that high work-load, poor behaviour of line managers, low skills and low wage rates are the notable reasons for high job turnover. Turnover, on the other hand, results in disruption in production. Sometimes existing workers face extra work-load due to the shortage of labour, and this ultimately reduces the job satisfaction. From this study, it has been found that the efficiency rate of workers is relatively low where there is a high work-load. Huselid (1995) also comments that work pressure in manufacturing firms reduces employee morale and commitment towards the organisation. This study finds that there is also high demand of employee's work life balance in the RMG sector. At present, RMG workers in Bangladesh are reluctant to do over time, work at the weekend and long shift, as they need time off for friends, family and entertainment. Results of this study depict that organisation without flexibility in work schedule and target, health and safety, holiday package and friendly work environment cannot attract potential workers. Miller and Rosse (2002) also note that organisation must consider employee's work life balance in order to retain skilled workers and increase job satisfaction. At present, garment workers are aware about their employment rights, wages, working hours, incentives and other benefits related with their employment (Rahman, Bhattacharya and Moazzem 2008). Workers expect to get respect from their supervisors and managers. Poor relationship between workers and supervisors is the source of conflict and sometimes workers are reluctant to work because of the poor relationship. Rewards based on individual performance motivate workers.

This study also finds out that there is a change in employee attitudes and behaviour in the RMG sectors of Bangladesh and the sense of self-respect among the workers is increasing. Workers often negotiate with management when there is any change in production planning and process. Line managers need to show respect and motivate the workers as skilled workers are generally more sensitive to self-respect. Unfortunately, the line managers in the RMG sector of Bangladesh are not well trained on labour management and they have regular conflict with workers (Rahman and Anwar 2007). Hay (2002) notes that poor relationship between employers and employees is a source of conflict and encourages employees to leave the organisation. This study finds that line managers react negatively in the case of any direct communication between workers and higher authority, as they take it as break in chain of command. Mutual understanding among workers and managers is also absent in the RMG sector. Worker's motivation also reduces due to the insufficient pay and incentives in the RMG sector. From the analysis it is clear that workers are not satisfied with their pay even though employers paying standard salary; workers believe that it is not sufficient enough to motivate them for higher productivity. Pay discrimination in different departments, group reward and delay in paying monthly salary have negative influence on workers. At the same time, external factors like trade union influence employees for unrest.

In summary, this study offers several suggestions in order to resolve the problems of labour unrest and conflict in the RMG sector of Bangladesh. This unrest needs a solution to reduce cost of production and to attract and retain 
international buyers (Haider 2007). The RMG are requiring to compliance with labour law (Rahman, , Bhattacharya and Moazzem 2008), ensuring appropriate financial benefit plans (Rahman, Bhattacharya and Moazzem 2008), improving working environment (Abdullah 2009; \& Robbani 2000), providing training (Abdullah 2005b; \& Chowdhury Ali and Rahman 2005) to semiskilled workers, removing gender discrimination, improving mutual understanding among workers and supervisors (Rahman, Bhattacharya and Moazzem 2008), providing maternity leave, removing relocation among different floors, providing residence facility (Absar 2001), arranging recreational activities and introducing individual performance based reward (Chowdhury, Ali and Rahman , 2005) and participative management system in the garment sector.

Line managers can also play an important role to remove the anti-trust and misunderstanding from the workers. They can have regular discussion with the workers regarding performance, development and learning needs. According to Guest (2007), line managers need to be trained enough on people management skills.

Presence for an effective communication channel to remove the conflicts is becoming essential. There is a need for participative management between workers and supervisors. Compensation and other benefits should be based on individual performance, and organisations must have human resource planning and long-term employment benefit package to prevent labour crisis. This study has been conducted in only one group. Further study is needed to include more garment factories to explore the causes and remedies of labour unrest in the RMG sector of Bangladesh. Moreover, results of this study may be further cross validating with using different research methodology such as questionnaire survey or in-depth interview.

\section{References}

Abdin, M. J. (2008). Overall Problems and Prospects of Bangladeshi Ready-Made Garment Industry. [Online] Available: http://ssrn.com/abstract $=1117186$ (11 June, 2011)

Abdullah, A.Y. M. (2009). The Influence of Work Environment and the Job Satisfaction on the Productivity of the RMG Workers in Bangladesh. Journal of Management, 1 (1): 43-55.

Abdullah, A.Y.M. (2005a). Labor Productivity and Wastage: The Two Sides of a Coin Bangladeshi RMG Perspective. The AIUB Journal of Business and Economics, 4(2):37-55.

Abdullah, A.Y.M. (2005b). Productivity Development is a Very Crucial Way Out to Face the Post Multi Fiber Agreement Challenges for Bangladesh. Journal of Business Administratio, 31(3): 107-129.

Absar, S. S. (2001). Problems Surrounding Wages: Readymade Garments Sector in Bangladesh. Labour and Management in Development, 2 (7): 2-17.

Ahmed, F.A. (2001). Strategic Human Resource Management: Linking Human Resource Management with Corporate Strategy. Journal of Business Studies, 12 (1).

Appelbaum, et al. (2000). Manufacturing Advantage: Why High Performance Work Systems Pay off. Ithaca: Cornell University Press.

Batt, R. (2002). Managing Customer Services: Human Resource Practices, Quit Rates and Sales Growth. Academy of Management Journal, 45: 587-597. http://dx.doi.org/10.2307/3069383

Becker, B. E., and Huselid, M.A. (1998). High-Performance Work Systems and Firm Performance: a Synthesis of Research and Managerial Implications. Research in Personnel and Human Resource Management, (6th ed.). Greenwich, CT: JAI Press.

Berik, G., and Rodgers, Y.V.D.M. (2008). Options for Enforcing Labor Standards: Lessons from Bangladesh and Cambodia. Department of Economics Working Paper Series. Working Paper No: 2008-14. Salt Lake City. [Online] Available: http://www.econ.utah.edu ( 12 June, 2011)

Bhattacharya, Debapriya and Mustafizur Rahman (2001). "Bangladesh's Apparel Sector: Growth Trend and the Post-MFA Challenges." In Pratima Paul-Majumder and Binayak Sen (eds.) Growth of Garment Industry in Bangladesh: Economic and Social Dimensions. Dhaka: Bangladesh Institute of Development Studies.

Birdi, et.al. (2008). The Impact of Human Resource and Operational Management Practices on Company Productivity: a Longitudinal Study. Personnel Psychology, 61: 467-501. http://dx.doi.org/10.1111/j.1744-6570.2008.00136.x

Chowdhury, M.A.M., Ali, M.M., and Rahman, R. (2005). WTO, Post MFA Era and the Bangladesh RMG Sector: An Assessment of the performance and challenges. Journal of the Institute of Bankers Bangladesh, 52 (2):87-120.

Clark, C., and Kanter, S. (2010/2011). Violence in the Readymade Garments (RMG)Iindustry in Bangladesh. Center for International and Comparative Studies. University of Michigan. 3 (1):6-12. 
CPD (Centre for Policy Dialogue) (1997). Crisis in Governance: A Review of Bangladesh's Development. University Press Ltd., Dhaka, Chapter 8. (cited in World Bank, 1999).

Export Promotion Bureau. (2010). Export Growth in RMG, Bangladesh Ministry of Commerce. [Online] Availableat:http://www.epb.gov.bd/index.php?NoParameter\&Theme=default\&Script=exportgrowth $(12$ June, 2011).

Export Promotion Bureau (2010). Export Trend Index, Bangladesh Ministry of Commerce. [Online] Available: http://www.epb.gov.bd/index.php?NoParameter\&Theme=default\&Script=exporttrend (7 June, 2011).

Guest, D. (2007). HRM and the Worker: Towards a New Psychological Contract. International Journal of Human Resource Management, 12 (7): 1092-1106.

Haider, Mohammad. Z. (2007). Competitiveness of the Bangladesh Ready-made Garment Industry in Major International Markets. Asia-Pacific Trade and Investment Review, 3(1).

Hay, M. (2002). Strategies for Survival in the War or Talent. Career Development International, 7 (1): 52-55

Henderson, Naomi R. (2009). Managing Moderator Stress: Take a Deep Breath. You Can Do This!. Marketing Research, 21 (1): 28-29.

Holtom, et al. (2005). Shocks as Causes of Turnover: What they are and How Organisation Can Manage Them. Journal of Human Resource Management, 44 (3): 337-352. http://dx.doi.org/10.1002/hrm.20074

Hossain, H., Jahan, R., and Sobhan, S. (1990). No Better Option? Industrial Women Workers in Bangladesh. Dhaka.: University Press Limited,

Huda et al. (2007). HRM Practices and Challenges of Non-government Development Organisation: An Empirical Study on Bangladesh. Journal of Management, 9(1): 35-49.

Huges, J., and Bozionelos, N. (2007). Work Life Balance as Source of Job Dissatisfaction and Withdrawal Attitudes. Personnel Review, 36 (1): 145-154. http://dx.doi.org/10.1002/hrm.20074

Huselid. (1995). The Impact of Human Resource Management Practices on Turnover, Productivity and Corporate Financial Performance. Academy of Management Journal, 38 (3): 635-672. http://dx.doi.org/10.2307/256741

Ichniowski et al. (1997). The Effects of Human Resource Management Practices on Productivity. American Economic Review, 87: 291-313.

Islam, M. S., and Ahmed, S. (2010). Contemplating Sustainable Solutions to Garments Sector Unrest. The Daily Star, 10 July

Islam, Mafizul A.F.M. (1984). Notes on the Growth of Bangladesh Garments Industry. The Journal of Management Business and Economics, 10(4): 536.

Jamaly, R., and Wickramanayake (1996). Women Workers in the Garment Industry in Dhaka, Bangladesh. Development in Practice, 6(2): 150-160.

Khan, M. A. (2010). Effects of Human Resource Management Practices on Organisation Performance: An Empirical Study of Oil and Gas Industry in Pakistan. European Journal of Economics, Finance and Administrative Sciences, 24: 158-175.

Lloyed, L. Bryars and Leslie, Rue (2000). Human Resource Management. $\left(6^{\text {th }}.\right)$. Irwin user page, McGraw-Hill, North America

MacDuffie, J.P. (1995). Human Resource Bundle and Manufacturing Performance: Organisational Logic and Flexible Production Systems in the World Auto Industry. Industrial and Labour Relations Review, 48: 197-221. doi:10.2307/2524483

Mahmood, M. (2004). The Institutional Context of Human Resource Management: Case Studies of Multinational Subsidiaries in Bangladesh. Doctoral Dissertation, University of Manchester, UK.

Marchington, M., and Wilkinson, A. (2008). Human Resource Management at Work: People Management and Development. (4th ed.). CIPD: London.

Miller, H., and Rosse, J. (2002). Emotional Reserve and Adaptation toJjob Dissatisfaction. The Psychology of Work: Theoretically based Empirical Research. Hillsdale, NJ: Erlbaum.

Morgan D.L., and Spanish, M.T. (1984). Focus Groups: A New Tool for Qualitative Research. Qualitative Sociology, 7: 253-270. http://dx.doi.org/10.1007/BF00987314 
Paul-Majumder, P. (1998). Health Status of the Garment Workers in Bangladesh: Findings from a Survey of Employers and Employees. Bangladesh Institute of Development Studies, Dhaka. 24 (1): 204-225.

Powell R.A., and Single, H.M. (1996). Focus Groups. International Journal of Quality in Health Care, 8 (5): 499-504. http://dx.doi.org/10.1093/intqhe/8.5.499

Quddus, M., and Rashid, S. (1999). Garment Exports from Bangladeshi: An Update and Evaluation. Journal of Business Studies, 1 (1):28-38.

Robbani, M.G. (2000). World Trade Organisation and the Ready Made Garment Industry of Bangladesh: A Critical Analysis. Journal of Business Studies, 2(2): 16-27.

Rabiee, Fatemeh. (2004). Focus Group Interview and Data Analysis. Proceedings of the Nutrition Society, 63: 655-660

Rahman, Mustafizur, Bhattacharya, Debapriya and Moazzem, Khondaker Golam. (2008). Bangladesh Apparel Sector in Post MFA Era: A Study on the Ongoing Restructuring Process. Dhaka: Centre for Policy Dialogue in association with IFC and SEDF.

Rahman, N., and Anwar, G.M.J. (2007). Sustainability of RMG Sector of Bangladesh as a Globally Competitive Industry: Porters Diamond Perspective. Journal of Business Studies, 28(2): 99-132.

Rock, M. (2001). Globalisation and Bangladesh: The Case of Export Oriented Garment Manufacture. South Asia, 24(1): 201- 225. http://dx.doi.org/10.1080/00856400108723430

Samad, S. (2006). The Contribution of Demographic Variables: Job Characteristics and Job Satisfaction on Turnover Intentions. Journal of International Management Studies, 1(1): 128-137.

Sarker, Md. M.R. (1997). Status of the Workers in the Garment Industries of Bangladesh. A Study on Socio-economic Perspective. Journal of Business Studies, 18(1): 153-168.

Schuler, S. (1990). Repositioning the Human Resource Function: Transformation or Demise? Academy of Management Executive, 4(3). 49-60. http://dx.doi.org/10.5465/AME.1990.4274667

Siddiqi, H.G.A. (2005). The Ready Made Garment Industry of Bangladesh. ( $2^{\text {nd }}$ ed.). Dhaka: The University Psress Limited.

Spinanger, D. (2001). The WTO, ATC and Textile and Clothing in a Global Perspective: What's in it for Bangladesh? Centre for Policy Dialogues Paper-8: 3-10. CPD: Dhaka.

Taylor, S. (2008). People Resourcing. (4th ed.) CIPD: London.

Uddin, M.S., and Jahed, M.A. (2007). Garments Industry: A Prime Mover of the Social Economic Development of Bangladesh. The Cost and Management, 35(1): 59-70.

Uddin, Md Abbas. (2006). Readymade Garments Industry of Bangladesh: How the Industry is Affect in Post MFA Period? M. acts and design thesis. Curtin University of Technology, Perth, Australia.

World Bank (1999). Bangladesh: Key Challenges for the Next Millenniu. p. 27.

Wright. et al. (2003). The Impact of HR Practices on the Performance of Business Units. Human Resource Management Journal, 13(3): 21-36. http://dx.doi.org/10.1111/j.1748-8583.2003.tb00096.x

Zawiah, S., and Taha, D. (2006). The Effect of Job and Environmental Factors on Job Satisfaction in Automotive Industries. International Journal of Occupational Safety and Ergonomics, 12(3): 267-280.

Table 1. Export Trend Index (2010)

\begin{tabular}{|l|l|l|}
\hline SL & Sectors & \% of foreign exchange \\
\hline 1 & Woven Garments & $37.11 \%$ \\
\hline 2 & Knitwear & $40.01 \%$ \\
\hline 3 & Frozen Food & $2.73 \%$ \\
\hline 4 & Jute Goods & $4.86 \%$ \\
\hline 5 & Leather & $1.40 \%$ \\
\hline 6 & Agri Products & $1.50 \%$ \\
\hline 7 & Engg. Products & $1.92 \%$ \\
\hline 8 & Footwear & $1.26 \%$ \\
\hline 9 & Other & $9.21 \%$ \\
\hline
\end{tabular}


Table 2. Export Growth in RMG (2010)

\begin{tabular}{|l|l|l|l|l|}
\hline YEARS & \multicolumn{3}{|c|}{ MILLION US\$ } & \\
\hline & WOVEN & KNIT & Total & GROWTH \\
\hline $2003-04$ & 3,538 & 2,148 & 5,686 & $16 \%$ \\
\hline $2004-05$ & 3,598 & 2,820 & 6,418 & $13 \%$ \\
\hline $2005-06$ & 4,084 & 3,817 & 7,901 & $23 \%$ \\
\hline $2006-07$ & 4,658 & 4,554 & 9,212 & $17 \%$ \\
\hline $2007-08$ & 5,169 & 5,533 & 10,702 & $16 \%$ \\
\hline $2008-09$ & 5,919 & 6,429 & 12,348 & $15 \%$ \\
\hline $2009-10$ & 6013 & 6483 & 12,497 & $1 \%$ \\
\hline
\end{tabular}

Table 3. List of Participants

\begin{tabular}{|c|c|c|c|c|c|}
\hline $\begin{array}{l}\text { SL/ } \\
\text { Code }\end{array}$ & Designation & $\begin{array}{l}\text { SL/ } \\
\text { Code }\end{array}$ & Designation & SL/ Code & Designation \\
\hline \multirow[t]{4}{*}{ F.1.1 } & \multirow{4}{*}{$\begin{array}{c}\text { Sr. Coordinator, Maintenance and } \\
\text { Engineering }\end{array}$} & F.2.1 & $\begin{array}{l}\text { Ast. Manager - } \\
\text { Work Study }\end{array}$ & F.3.1 & Ast. Merchandiser \\
\hline & & F.2.2 & $\begin{array}{c}\text { Ast. } \\
\text { Manager-Cutting }\end{array}$ & F.3.2 & Finishing Manager \\
\hline & & \multirow[t]{2}{*}{ F.2.3 } & \multirow{2}{*}{$\begin{array}{l}\text { Ast. Manager - } \\
\text { Merchandising } \\
\text { and Marketing }\end{array}$} & F.3.3 & Executive Mechanics \\
\hline & & & & \multirow[t]{2}{*}{ F.3.4 } & \multirow[t]{2}{*}{$\begin{array}{l}\text { Ast. Manager - Quality } \\
\text { Control }\end{array}$} \\
\hline \multirow[t]{2}{*}{ F.1.2 } & \multirow[t]{2}{*}{ Technical Manager } & \multirow[t]{2}{*}{ F.2.4 } & \multirow{2}{*}{$\begin{array}{l}\text { Ast. Manager - } \\
\text { Merchandising }\end{array}$} & & \\
\hline & & & & F.3.5 & $\begin{array}{l}\text { Ast. Manager - } \\
\text { Security }\end{array}$ \\
\hline F.1.3 & Ast. Production Manager & F.2.5 & $\begin{array}{c}\text { Quality Control } \\
\text { Manager }\end{array}$ & F.3.6 & $\begin{array}{l}\text { Admin and } \\
\text { Compliance }\end{array}$ \\
\hline F.1.4 & Marketing Manager & F.2.6 & $\begin{array}{l}\text { Finishing } \\
\text { Manager }\end{array}$ & F.3.7 & $\begin{array}{l}\text { Ast. Manager - Work } \\
\text { Study }\end{array}$ \\
\hline F.1.5 & Marchendiser & F.2.7 & Head of HR & F.3.8 & Ast. Manager \\
\hline \multirow[t]{4}{*}{ F.1.6 } & \multirow[t]{4}{*}{ Executive, HR and Compliance } & \multirow[t]{4}{*}{ F.2.8 } & \multirow[t]{4}{*}{$\begin{array}{l}\text { Executive, HR } \\
\text { and Compliance }\end{array}$} & F.3.9 & $\begin{array}{l}\text { Department Manager } \\
\text { Admin, HR \& } \\
\text { Compliance }\end{array}$ \\
\hline & & & & F.3.10 & Manager Knitting \\
\hline & & & & F.3.11 & $\begin{array}{l}\text { Ast. Production } \\
\text { Manager }\end{array}$ \\
\hline & & & & F.3.12 & Finishing Manager \\
\hline
\end{tabular}

